\title{
Znaczenie wskaźnika neutrofilowo-limfocytowego w chorobach układu sercowo-naczyniowego
}

\author{
The meaning of neutrophil-lymphocyte ratio \\ in patients with cardiovascular diseases
}

\author{
Justyna Kuźniar-Placek ${ }^{1}$, Magdalena Pacyna ${ }^{2}$, Andrzej Jaroszyński ${ }^{1}$ \\ ${ }^{1}$ Katedra i Zakład Medycyny Rodzinnej Uniwersytetu Medycznego w Lublinie \\ ${ }^{2}$ Niepubliczny Zakład Opieki Zdrowotnej Diaverum w Lublinie
}

\section{Streszczenie}

Choroby układu sercowo-naczyniowego (CVD) wciąż są najczęstszą przyczyną umieralności. Istotną rolę w rozwoju tych chorób odgrywa stan zapalny niskiego stopnia. Jednym z wyznaczników takiego stanu jest wskaźnik neutrofilowo-limfocytowy (NLR). Określa się go jako iloraz liczby granulocytów obojętnochłonnych i limfocytów. Prawidłowa wartość NLR pozostaje nieznana. Wartości prawidłowe i patologiczne zależą od jednostki chorobowej. Udowodniono istotne znaczenie NLR w niektórych CVD, takich jak choroba niedokrwienna serca, zaburzenia rytmu serca, nadciśnienie tętnicze. W tych jednostkach chorobowych NLR stanowi istotny czynnik predykcyjny między innymi gorszego rokowania, krótszego czasu przeżycia oraz wystąpienia groźnych dla życia zaburzeń rytmu. Szerokie rozpowszechnienie CVD, także w populacji osób młodych, jest przyczyną poszukiwania nowych, tanich i łatwo dostępnych metod wykrywania tych chorób.

Słowa kluczowe: wskaźnik neutrofilowo-limfocytowy, choroby układu sercowo-naczyniowego, stan zapalny

Folia Cardiologica 2016; 11, 6: 525-528

\section{Wstęp}

Choroby układu krążenia (CVD, cardiovascular diseases) wciąż są najczęstszą przyczyną umieralności. Najważniejszym czynnikiem odpowiadającym za tak wysoką umieralność jest choroba niedokrwienna serca. Powodami znaczącej części incydentów kardiologicznych są duże rozpowszechnienie, nadal niska skuteczność ograniczania modyfikowalnych czynników ryzyka oraz ich niedostateczna wykrywalność. Szerokie rozpowszechnienie CVD, także w populacji osób młodych, jest przyczyną poszukiwania nowych, tanich i łatwo dostępnych metod wykrywania CVD $[1,2]$.

Jak wiadomo, stan zapalny i stres oksydacyjny odgrywają istotną rolę w rozwoju CVD. Jest to proces zapalny ni- skiego stopnia, ponieważ stężenie cytokin czy białek ostrej fazy jest o wiele niższe niż w klasycznym stanie zapalnym. Udokumentowanie roli procesu zapalnego w wystąpieniu incydentów sercowych doprowadziło do zwrócenia szczególnej uwagi na różne markery zapalne jako wskaźniki pomocne w ocenie ryzyka wystąpienia i rozwoju CVD. Ta wiedza doprowadziła do wielu nowych badań ukierunkowanych właśnie na badanie czynników stanu zapalnego. Jednym z nim jest wskaźnik limfocytowo-neutrofilowy (NLR, neutrophil-lymphocyte ratio). To tani i łatwo dostępny marker, który w ostatnich latach był szczególnie intensywnie badany $[3,4]$.

Wskaźnik neutrofilowo-limfocytowy określa się jako iloraz liczby granulocytów obojętnochłonnych i limfocytów. Uważa się go za pośredni wskaźnik subklinicznego stanu 
zapalnego. Najnowsze badania wskazują, że stosunek poszczególnych typów krwinek białych ma ważniejszą wartość prognostyczną dla CVD niż całkowita liczba krwinek białych [5]. Warto podkreślić fakt, że nadal nie ustalono wartości prawidłowych i nieprawidłowych tego wskaźnika. Wartości te różnią się zależnie od jednostki chorobowej.

Wykazano, że NLR w CVD jest czynnikiem predykcyjnym między innymi wystąpienia zaburzeń rytmu serca, wiąże się z częstszymi dekompensacjami pacjentów z zastoinową niewydolnością serca, ich krótszym czasem przeżycia, gorszą przeżywalnością pacjentów poddanych operacji wymiany zastawki aortalnej czy wzrostem śmiertelności wśród pacjentów z zespołami wieńcowymi. Wykazano korelacje tego wskaźnika z takimi skalami jak GRACE (GRACE Risk Score) czy SYNTAX (SYNTAX Score) [6]. Mimo dobrej znajomości markerów zapalnych to właśnie NLR wydaje się przeżywać renesans jako wartościowy biomarker o dużym znaczeniu prognostycznym [7].

\section{Omówienie}

\section{Nadciśnienie tętnicze}

Stan zapalny niewielkiego stopnia jest znaną składową patogenetyczną w rozwoju nadciśnienia tętniczego. W następstwie wieloletnie nadciśnienie prowadzi do uszkodzenia narządów. Wskaźnik limfocytowo-neutrofilowy jest prostym i niezawodnym wskaźnikiem procesu zapalnego; może być również użyteczny w ocenie klinicznej nadciśnienia tętniczego. Podwyższone wartości NLR istotnie korelują ze zwiększonym ryzykiem wystąpienia nadciśnienia. Tym samym NLR może być przydatny w wyjaśnianiu mechanizmów leżących u podstaw rozwoju nadciśnienia. Nowe metody terapeutyczne ukierunkowane na stan zapalny można by wykorzystać do kontroli ciśnienia tętniczego i uszkodzenia narządowego w przebiegu nadciśnienia tętniczego [8].

\section{Choroby naczyń}

Zastosowanie NLR zaobserwowano także w chorobach naczyń obwodowych. Wśród pacjentów z chorobą Kawasaki okazało się, że NLR jest wyższy u chorych, u których stwierdzono oporność na podane dożylnie immunoglobuliny niż u chorych, którzy dobrze zareagowali na leczenie immunoglobulinami. Wśród pacjentów z wyższymi wartościami NLR znacznie częściej obserwowano powikłania niż u pacjentów z wartościami niższymi. Do powikłań tych należały poszerzenie naczyń wieńcowych oraz tętniaki. W ostrej fazie gorączki i 2 dni po dożylnym podaniu immunoglobulin NLR, odpowiednio, powyżej 5,49 i 1,26 zwiększał ryzyko oporności na dożylne immunoglobuliny. Wartość NLR ponad 1,01 (2 dni po dożylnym podaniu immunoglobulin) można zostać uznany za czynnik predykcyjny rozwoju tętniaków oraz oporności na immunoglobuliny dożylne [9].
Kolejną chorobą naczyń, w której określono wpływ NLR, jest choroba Behçeta. Wiąże się ona z dysfunkcją śródbłonka i przewlekłym stanem zapalnym. U pacjentów z chorobą Behçeta stwierdzono umiarkowane dodatnie zależności między wartością NLR a stężeniem białka C-reaktywnego (CRP, C-reactive protein) oraz grubością kompleksu intima-media tętnicy szyjnej wewnętrznej. Dodatnią wartość predykcyjną dla aktywności choroby zanotowano w przypadku NLR ponad 1,29. Zatem NLR może być użytecznym wskaźnikiem aktywności choroby wśród pacjentów z chorobą Behçeta [10].

\section{Zaburzenia rytmu serca}

Znaczenie NLR obserwuje się także u pacjentów z zaburzeniami rytmu serca. Wśród pacjentów z niezastawkowym migotaniem przedsionków zaobserwowano istotnie wyższy NLR, jeśli doszło do rozwoju skrzepliny w lewym przedsionku (NLR 2,7 \pm 1,1) [11].

Wykazano także, że u pacjentów z wyższymi wartościami NLR (mediana 3,0) w okresie przedoperacyjnym, poddanych zabiegowi pomostowania tętnic wieńcowych, częściej dochodziło do epizodów migotania przedsionków trwających ponad 30 s niż u pacjentów z niższymi NLR. Nie stwierdzono różnic pod względem całkowitej liczbie krwinek białych ani wartości CRP. Również poooperacyjny NLR był wyższy u pacjentów z migotaniem przedsionków (2. dnia mediana 9,2) i wiązał się z wyższym ryzykiem pojawienia się tego zaburzenia rytmu [12].

\section{Choroba niedokrwienna serca}

Leukocyty odgrywają znaczącą rolę nie tylko w tworzeniu blaszki miażdżycowej, ale także w formowaniu skrzepliny w ostrych zespołach wieńcowych (ACS, acute coronary syndrome). Zaobserwowano, że NLR, obok innych markerów stanu zapalnego, ma dużą wartość predykcyjną gorszego rokowania. U pacjentów, u których doszło do wytworzenia skrzepliny w naczyniu wieńcowym, obserwuje się wyższe wartości neutrofilów, płytek krwi oraz NLR, znacząco natomiast obniża się liczba limfocytów [13].

Ponadto NLR jest także istotnym czynnikiem wyższego ryzyka zgonu oraz przeszczepienia serca wśród pacjentów z zaawansowaną niewydolnością serca [14]. Ciekawa obserwacja dotyczyła chorych, którzy przebyli zawał serca z uniesieniem odcinka ST (STEMI, ST-elevation myocardial infarction). Stwierdzono, że u tych osób wartość NLR przekraczająca 3,7 wiązała się z wyższym ryzykiem powikłania w postaci pęknięcia wolnej ściany mięśnia sercowego (czułość 82,6\%, specyficzność 46,9\%). Wskaźnik ten, obok wieku, nadciśnienia tętniczego i podwyższonego stężenia kreatyniny, uznano za niezależny czynnik ryzyka pęknięcia wolnej ściany mięśnia sercowego w przebiegu STEMI [15]. 
Pacjenci, którzy byli poddawani pierwotnej przezskórnej angioplastyce wieńcowej, cechowali się wyższym ryzykiem zarówno zgonu wewnątrzszpitalnego jak i ryzyka odległego, jeśli stwierdzono u nich podwyższone wartości NLR i wskaźnika płytkowo-limfocytowego lub tylko jednego z nich z nich [16]. Podobna obserwacja dotyczyła pacjentów poddanych operacjom kardiochirurgicznym. Wartość NLR ponad 3,3 przed operacją serca i większa niż 5 przed operacją naczyniową wiązała się z większą śmiertelnością w okresie obserwacji wynoszącym 34,8 miesiąca [17].

U pacjentów ze STEMI, którzy przebyli przezskórną angioplastykę wieńcową, NLR był dodatnio skorelowany z cTFC (corrected TIMI frame count) i większą śmiertelnością wewnątrzszpitalną, dlatego NLR można uznać za niezależny wskaźnik przepływu wieńcowego po przezskórnej angioplastyce wieńcowej. Statystycznie znaczący wzrost śmiertelności długoterminowej zaobserwowano u pacjentów już z NLR ponad 3, zwłaszcza z NLR w zakresie 3,0-6,4, ale także z NLR przekraczającym 6,4 [18].

\section{Przewlekła choroba nerek}

U pacjentów z przewlekłą chorobą nerek często stwierdza się podwyższone wartości troponin, co może być spo- wodowane chorobą podstawową, a nie na przykład ACS. Dlatego poszukiwano innego wskaźnika, który w tej grupie pacjentów mógłby być wyznacznikiem zwiększającym prawdopodobieństwo rozpoznania ACS. Okazało się, że i w tym przypadku takimi wskaźnikami mogą być NLR, jak również całkowita liczna neutrofilów. Pacjentów, u których NLR przekraczał 7,4, cechowało 2,18 razy większe prawdopodobieństwo wystąpienia zawału serca. Wydaje się to bardzo istotne w dobie wysokiej czułości oznaczeń troponin [19].

\section{Podsumowanie}

Wskaźnik neutrofilowo-limfocytowy okazuje się przydatnym i łatwo dostępnym narzędziem u pacjentów, którzy ze względu na wyższe ryzyko gorszego rokowania wymagają zwiększonej uwagi. Wprowadzenie tego wskaźnika do codziennej praktyki może ułatwić ocenę ryzyka i w ten sposób wpłynąć na poprawę rokowania u osób z CVD obarczonych najwyższym ryzykiem.

\section{Konflikt interesów}

Autorzy nie zgłaszają konfliktu interesów.

\section{Abstract}

Cardiovascular diseases (CVD) are still the most often cause of mortality in the population. The important role in the development of cardiovascular diseases is a low-grade inflammation. One of the indicators of this state is neutrophil-lymphocyte ratio (NLR). Neutrophil-lymphocyte ratio is defined as the quotient of the number of neutrophils and lymphocytes. Still unknown is the normal value of NLR. Normal and pathological values depend on the kind of disease. The meaning of NLR has been proven in some cardiovascular diseases such as ischemic heart disease, arrhythmias or hypertension. In these diseases, NLR is an important predictor of worse prognosis, shorter time of survive or life-threatening arrhythmias. The prevalence of CVD, even in young population, is the main cause of the search for new, low-cost and available methods for diagnosing cardiovascular diseases.

Key words: neutrophil-lymphocyte ratio, cardiovascular diseases, inflammation

Folia Cardiologica 2016; 11, 6: 525-528

\section{Piśmiennictwo}

1. Dostępne na: http://ec.europa.eu/eurostat/statistics-explained/ /index.php/Causes_of_death_statistics/pl. Data dostępu: 4.04.2016 r.

2. Zdrojewski T., Ignaszewska-Wyrzykowska A., Wierucki Ł. i wsp. Modelowy projekt prewencji chorób układu krążenia na przykładzie doświadczeń Programu SOPKARD. Choroby Serca i Naczyń 2004; 1: 115-129.

3. Głuszek J. Niedokrwienie serca i nadciśnienie tętnicze u chorych na przewlekłą obturacyjną chorobę płuc i obturacyjny bezdech senny. Pneumonol. Alergol. Pol. 2013; 81: 567-574.

4. Nowicka G. Praktyczne możliwości wykorzystania markerów stanu zapalnego w ocenie ryzyka choroby niedokrwiennej serca. Przew. Lek. 2005; 2: 52-55.
5. Białas M., Gryszkiewicz M. Podejrzenie ostrego zapalenia wyrostka robaczkowego - trudności w rozpoznaniu i metody wspomagające diagnostykę. Now. Lek. 2006; 75: 184-192.

6. Soylu K., Gedikli Ö., Dagasan G. i wsp. Neutrophil-to-lymphocyte ratio predicts coronary artery lesion complexity and mortality after non-ST-segment elevation acute coronary syndrome. Rev. Port. Cardiol. 2015; 34: 465-471.

7. Maxwell E., Tariq B. Neutrophil to lymphocyte ratio (NLR) and cardiovascular diseases: an update. Expert Rev. Cardiovasc. Ther. 2016; 14: 573-577.

8. Xing L., Qing Z., Hongmei W. i wsp. Blood neutrophil to lymphocyte ratio as a predictor of hypertension. Am. J. Hypertens. 2015; 28: 1339-1346. 
9. Kee-Soo H., Jeehoo L., Gi Young J. i wsp. Value of neutrophil-lymphocyte ratio in predicting outcomes in Kawasaki disease. Am. J. Cardiol. 2015; 116: 301-306.

10. Ozturk C., Balta S., Balta I. i wsp. Neutrophil-lymphocyte ratio and carotid-intima media thickness in patients with Behçet disease without cardiovascular involvement. Angiology 2015; 66: 291-296.

11. Yalcin M., Aparci M., Uz O. i wsp. Neutrophil-lymphocyte ratio may predict left atrial thrombus in patients with nonvalvular atrial fibrillation. Clin. Appl. Thromb. Hemost. 2015; 21: 166-171.

12. Gibson P., Cuthbertson B., Croal B. i wsp. Usefulness of Neutrophil/ /Lymphocyte Ratio As Predictor of New-Onset Atrial Fibrillation After Coronary Artery Bypass Grafting. Am. J. Cardiol. 2010; 105: 186-191.

13. Yilmaz M., Tenekecioglu E., Arslan B. i wsp. White blood cell subtypes and neutrophil-lymphocyte ratio in prediction of coronary thrombus formation in non-ST-segment elevated acute coronary syndrome. Clin. Appl. Thromb. Hemost. 2015; 21: 446-452.

14. Benites-Zapata V., Hernandez A., Nagarajan V. i wsp. Usefulness of neutrophil-to-lymphocyte ratio in risk stratification of patients with advanced heart failure. Am. J. Cardiol. 2015; 115: 57-61.
15. Ipek G., Onuk T., Karatas M. i wsp. Relationship between neutrophil-to-lymphocyte ratio and left ventricular free wall rupture in acute myocardial infarction. Cardiology 2015; 132: 105-110.

16. Çiçek G., Açıkgoz S., Bozbay M. i wsp. Neutrophil-lymphocyte ratio and platelet-lymphocyte ratio combination can predict prognosis in patients with ST-segment elevation myocardial infarction undergoing primary percutaneous coronary intervention. Angiology 2015; 66: 441-447.

17. Tze P., Anil A., Jigesh M. i wsp. Neutrophil-lymphocyte ratio as predictor of mortality and morbidity in cardiovascular surgery: a systematic review. ANZ J. Surg. 2015; 85: 414-419.

18. Wei P., Deliang Z., Canxiu Z. i wsp. Application of neutrophil/lymphocyte ratio in predicting coronary blood flow and mortality in patients with ST-elevation myocardial infarction undergoing percutaneous coronary intervention. J. Cardiol. 2015; 66: 9-14.

19. Nalbant A., Cinemre H., Kaya T. i wsp. Neutrophil to lymphocyte ratio might help prediction of acute myocardial infarction in patients with elevated serum creatinine. Pak. J. Med. Sci. 2016; 32: 106-110. 